DOI: $10.15276 /$ EJ.02.2020.12

DOI: $10.5281 /$ zenodo.4012476

UDC: 35.088 .3

JEL: E24, F66, J24, M54

\title{
THEORETICAL AND METHODOLOGICAL BASIS OF RESOURCING THE HUMAN CAPITAL MANAGEMENT OF AN ORGANIZATION
}

\author{
ТЕОРЕТИКО-МЕТОДИЧНИЙ БАЗИС РЕСУРСНОГО \\ ЗАБЕЗПЕЧЕННЯ УПРАВЛІННЯ ПЕРСОНАЛОМ ОРГАНІЗАЦЇ̈
}

\author{
Anzhela V. Kulinska, DEcon, Professor \\ Odessa National Polytechnic University, Odessa, Ukraine \\ ORCID: 0000-0002-3609-3697 \\ Email: anzelakulinskaa@gmail.com \\ Dmitry O. Kostyuk \\ Odessa National Polytechnic University, Odessa, Ukraine \\ Email: dmitrykostyuk830@gmail.com \\ Kateryna G. Topalova \\ Odessa National Polytechnic University, Odessa, Ukraine \\ ORCID: 0000-0002-8257-6972 \\ Email: katetopalova23@gmail.com
}

Recieved 15.02.2020

\begin{abstract}
Кулінська А.В., Костюк Д.О.,Топалова К.Г. Теоретико-методичний базис ресурсного забезпечення управління персоналом організації. Оглядова стаття.

Оскільки робота 3 персоналом, пов'язана 3 професійним добором, оплатою праці і професійним навчанням, що вимагає достатньої кількості необхідних ресурсів, тому забезпечення діяльності суб'єктів управління персоналом включає витрати на утримання та виконання функцій управління персоналом. У зв'язку із цим, для розвитку нашої держави особливо актуальним є питання зміни світогляду й настанов керівників організацій та представників органів державної влади на персонал як об'єкт управління. Тому в статті запропоновано та сформовано теоретико-методичний базис ресурсного забезпечення управління персоналом організації, який складається з нормативно-правової бази управління персоналом, науково-методичного супроводу управління персоналом, матеріально-технічної бази управління персоналом і фінансового забезпечення управління персоналом, що є необхідним для належного та ефективного виконання функцій управління персоналом працівникам служби персоналу та керівникам організацій.

Ключові слова: матеріально-технічна база, науково-методичний супровід, нормативно-правова база, організація, ресурсне забезпечення, теоретико-методичний базис, управління персоналом

Kulinska A.V., Kostyuk D.O., Topalova K.G. Theoretical and Methodological Basic of Resourcing the Human Capital Management of an Organization. Review article.

Considering that the work with staff is associated with professional selection, labour expence and vocational training, which requires sufficient resources, the provision of human capital management activities includes the cost of maintaining and performing human capital management functions. In this regard, the issue of changing the world-view and guidelines of heads of organizations and public authorities representatives on personnel as an object of management is especially important for our state's development. Therefore, the article proposes and forms the theoretical and methodological basis of resourcing the human capital management of an organization, which consists of legal framework for human capital management, scientific and methodological support of human capital management, material and technical base of human capital management and financial support for human capital management, which is necessary for proper and effective performance of human capital management functions by HR Department employees and heads of organizations.

Keywords: material and technical facilities, scientific and methodological support, regulatory and legal framework, organization, resourcing, theoretical and methodological basis, human capital management
\end{abstract}

oday goods or services production takes place in the harsh conditions of a competitive market. Competition takes place not only among goods and services producers, there is a campaign between organizations, political parties, states, and so on. Positive results of any social system are provided by its social factor, i.e. people. In order for an organization to function successfully, three prerequisites must be created: at the head of the organization and each structural unit to put highly qualified and patriotic leaders in the interests of the organization; to staff workplaces with performers whose qualifications and competencies would be adequate to the complexity of their job responsibilities; means of management to direct the activities of each individual employee and all together to achieve corporate goals of the organization. Everything else - capital, technology, investment - also play a significant role, but compared to the human factor - are of secondary importance.

In the developed world countries, activities in the field of human capital management are considered as profitable, and personnel costs - as an investment. The explanation here is simple - everything is done by 
people's minds and hands. Both domestic and world practice are rich in cases of bankruptcy of some enterprises, creation and prosperity of others. The global economic crisis has affected all countries and all organizations equally. But some companies survived because they were always ready for crisis situations. The latter have lost a lot, but stay afloat. Others were completely unable to withstand the crisis and capitulated. This unequal vulnerability of different companies is due to differences in management quality. For this purpose public administration bodies adopt relevant legislative acts, ministries and departments together with research organizations develop normative-legal and scientific-methodical documents, as work with people requires clear regulation of parties' rights and responsibilities to social and labour relations and their observance. established rules, norms and procedures.

\section{Analysis of recent resarches and publications}

Many well-known scientists from the state and regional administration, as well as human capital management specialists studied the key aspects of forming the theoretical and methodological basis of resourcing the human capital management of organizations, which is necessary for proper and effective performance of human resources management functions by HR Department employees or heads of organizations. Thus, L.V. Balabanova, O.V. Sardak [2], L.I. Mykhailova [7] and V.H. Shcherbak [10] emphasize that the legal and regulatory framework for human capital management, as one of the main components of human capital management resources, belongs to the agreements, at various levels to regulate industrial, labour, social and economic relations and to reconcile the interests of workers and owners.

However, O. Deliia [3], V.P. Mytsa [8] and V.A. Savchenko [9] note that scientific and methodological support is the understanding of the most complex problems and issues in the field of human capital management that arise from time to time, and the development of practical recommendations, methods and special instructional materials for organizations. In addition, the documents development by managers for scientific and methodological support of human capital management, in particular, human capital management policy, corporate code, regulations on the personnel reserves formation, regulations on the organizing the personnel adaptation, recommendations on personnel selection, regulations on personnel incentives and evaluation, training, retraining and advanced training, instructions on safety rules, regulations on the competition for the title of the best in the profession, etc., is relevant in the research of such scientists and specialists as V.I. Dovbenko ta V.M. Melnyk [4], O.V. Krushelnytska and D.P. Melnychuk [6].

However, the solution of human resources management problems with minimal labour and costs with the required quality in a timely manner is impossible without the use of modern means of computer, organizational equipment or operational printing. When determining the need for technical means it is necessary to take into account the functions and tasks of HR, complexity and timing of work, automation level of human capital management functions, types of media and volumes of input and output information, receipt frequency, storage time, methods and frequency of information issues are not sufficiently studied and require further and in-depth scientific analysis, which will be an impetus for the development of our state and change the worldview and guidelines of leaders of organizations and public authorities representatives of Ukraine on personnel as a subject of management.

\section{Unsolved aspects of the problem, which are the subject of this article}

According to the research results, the interest in the knowledge economy has increased since the goods producers realized that the era of extensive development of the industry is over. Natural resources are being depleted, new technologies are becoming more accessible, globalization is breaking down borders and customs barriers, and competition between producers is intensifying. Nowadays, the strategic resource of the organization has become staff, and the main competitive advantage - the management ability to provide state-of-the-art knowledge to employees faster than competitors.

According to N.P. Bazaliiska [1], K.B. Kozak and Yu.O. Ruban [5] it is also very important managers' ability with the help of personnel to effectively use the latest knowledge of employees and further increase them. According to domestic and international business practice, today human capital management has become one of the most important functions of management, and human capital management strategy has become a key part of the general strategy of enterprises. Specialists' training with knowledge of the latest theory and best practices of human capital management is an important task of higher education in Ukraine.

Moreover, the most successful enterprises are to some extent intelligent organizations that develop their key competencies based on knowledge, create conditions for their management, ensuring a sustainable increase in competitiveness in the global market. It is known that in the context of innovative strategy realization of continuous professional development and personnel knowledge management in the activities of many organizations a methodical system of personnel training and development, a system of personnel advanced training, a clear procedure for certification of managers, specialists and workers of leading professions, etc. have been created, implemented and put into operation.

In this regard, to form a theoretical and methodological basis for resourcing the human capital management of the organization, which is necessary for proper and effective performance of human capital management functions of HR Department employees and managers of organizations, it is necessary to solve the following tasks [2, 6, 9]: developing job models that reflect the requirements for knowledge, skills and values required to work in specific positions; requirements formulation to the structure and level of employees' competence, in 
particular, knowledge, skills, practical skills and communication skills; personnel skills development through training, evaluation and certification.

The aim of the article is to formulate the theoretical and methodological basis of resourcing the human capital management of the organization, which consists of regulatory framework for human capital management, scientific and methodological support of human capital management, material and technical base of human capital management and financial support of human capital management. effective performance of human capital management functions by HR Department employees and heads of organizations.

\section{The main part}

Since the main objective of regulatory and legal framework is social and labour relations regulation, tasks and responsibilities regulation, labour behaviour, employees and employers' rights and interests protection, the legal support of human capital management includes such procedures as development and approval of internal regulations, introduction changes and additions to regulations in accordance with changes occurring in the external and internal environment, as well as control over compliance with current labour legislation.

It is known that the regulatory and legal framework of human capital management management of the organization covers the following basic laws. The inalienable right of a Ukrainian citizen to work is guaranteed by the Constitution, which proclaims work to be free (art. 43). Everyone has the right to independently dispose of his or her abilities, to choose a type of work and a profession that he or she likes, to receive for his or her work a salary not lower than the minimum wages established by law, and to work in an appropriate manner, safe and healthy working conditions. Under the Constitution of Ukraine, everyone has the right to the free development of his or her personality [5].

According to many human capital management specialists $[4,7,10]$, the Code of Labour Laws (hereinafter referred to as the Labour Code) of Ukraine has a direct impact on the proper and effective performance of human capital management functions by HR Department employees and heads of organizations. The Labour Code of Ukraine defines the legal basis and guarantees for the exercise by Ukrainian citizens of the right to dispose of their abilities for productive and creative work. An additional point is that, in our opinion, during the the theoretical and methodological basis formation of resourcing the human capital management of the organization, which is necessary to change the worldview and guidelines of heads of organizations and government officials on personnel as a managementobject, attention should be paid to the following regulations. legal acts, these are:

The Law of Ukraine "On Employment of Population", which determines the legal, economic and organizational basis of employment and protection against unemployment, as well as social guarantees from the state in the exercise of citizens' right to work;

The Law of Ukraine "On Collective Bargaining Agreements and Accords", which defines the legal basis for the development, conclusion and implementation of collective agreements and contracts to promote the regulation of labour relations and employees and owners' socio-economic interests;

The Law of Ukraine "On the Procedure for Resolving Collective Labour Disputes (Conflicts)", which defines the legal and organizational principles for resolving collective labour disputes, and aims to ensure the parties interaction of social and labour relations in the collective labour disputes settlement;

The Law of Ukraine "On Remuneration of Labour", which defines the economic, legal and organizational principles of individuals' remuneration who are in employment on the basis of an employment contract with enterprises of all forms of ownership and management and individual citizens, and aims to ensure reproductive and incentive functions of wages;

The Law of Ukraine "On Labour Protection", which defines the basic provisions for the implementation of the citizens' constitutional right in protection of their lives and health in the process of work, regulates with the participation of relevant government agencies the relationship between an owner of an enterprise and an employee on the issues of safety, occupational health and the working environment, and establishes a uniform procedure for the organization of labour protection in Ukraine;

The Law of Ukraine "On Pension Provision", which guarantees all disabled citizens of Ukraine the right to material security at the expense of public consumption funds through the appointment of labour and social pensions and aims to take full account of community service as a welfare source of the people and everyone establishes the unity of conditions and norms of pension provision for employees.

Moreover, the regulatory and legal framework for personnel management includes bargains concluded at various levels to regulate industrial, labour, socio-economic relations and concur the interests of employees, owners and their authorized bodies [1]. Thus, the agreement at the state level regulates the basic principles and standards for the implementation of social and economic policy and labour relations, in particular guarantees of work and productive employment, minimum social guarantees of labour remuneration, the amount of the minimum subsistence level, social insurance, labour and rest regimes, working and environmental protection, meeting the spiritual needs of the population, etc.

It is known that the parties to the general agreement are trade unions and owners or their authorized bodies, which have united to conduct collective bargaining and conclude a general agreement, the enterprises employing employ the majority of state employees. At the sectoral level, the agreement regulates sectoral standards, in particular minimum wage guarantees in accordance with qualifications based on unified tariff system, minimum 
supplements and allowances, taking into account specific conditions; the working conditions of certain professional groups and categories of workers in the sector, minimum social guarantees, compensation, labour and employment benefits, working conditions and labour protection, housing, medical and cultural services; health and recreation organizations etc. The parties to the agreement at the sectoral level are the owners, owners' associations and their authorized bodies and trade unions or trade unions associations or other representative organizations of employees who have the appropriate powers to negotiate, conclude the agreement and implement its rules.

However, the agreement at the regional level regulates the social protection norms of employees of enterprises, including higher than the general agreement social guarantees, benefits and compensations. The agreement at the regional level is concluded between local authorities or regional associations of entrepreneurs, if they have the appropriate authority, and trade unions or other authorized labour collective bodies [8].

It is proved that enterprises must comply with the provisions and norms of general, sectoral, regional agreements when developing their own regulations relating to human resources management, as the different vulnerabilities of different enterprises due to peculiarities in the quality of human capital management. With the express aim of that, public administration bodies adopt relevant legislation, ministries and departments together with research organizations develop regulations, because working with people requires clear regulation of parties' rights and responsibilities to social and labour relations and their compliance with the rules, norms and procedures.

According to the scientific and methodological support of human capital management, as noted by L.V. Balabanova and O.V. Sardak [2], its purpose is a theoretical understanding of the most complex problems and issues in human capital management, practical recommendations development for enterprises, methods, special instructional materials, handbooks and advising employees on the application of such implementations. Thus, the Handbook of Qualification Characteristics of Employees' Professions (hereinafter referred to as the Handbook), systematized by types of economic activity, is a collection of descriptions of professions included in the Professions Classifier. The content of the issue or section of the issue consists of "Introduction" and "Qualification Characteristics", arranged in alphabetical order with serial numbers.

It is noted that the Handbook is used to solve such tasks as the development of job descriptions and work instructions, drafting regulations on structural units, assignment of qualification ranks and job categories, curriculum development, etc. The directory is used as a basic means of organizing wages, along with wages scale and salary schemes that determine the tariff conditions of remuneration.

At the same time, intersectoral labour rules and regulations are designed to regulate the same labour processes at enterprises of different types of activities. Intersectoral norms and standards of labour are developed by relevant research and design and technological organizations, taking into account organizational and technical conditions and progressive experience in the production and labour organization. Also a common type of documents relating to scientific and methodological support of human capital management are departmental technological developments, instructions, rules for performing certain processes and procedures in various types of economic activity.

Among the acts developed by international organizations, the United Nations (hereinafter UN) regulations and the conventions and recommendations of the International Labour Organization (hereinafter ILO) should be taken into account [9].Among the main UN legislative enactment proclaiming fundamental human rights, one can single out the Universal Declaration of Human Rights, which is a policy programme document and contains a package of basic inalienable human rights to work and free occupation choice, protection against unemployment, fair and favourable working conditions. equal pay for the same work without any discrimination, fair and satisfactory remuneration to ensure the dignified existence of an individual and his/her family, the establishment and joining of trade unions to protect the interests of workers, leisure and recreaton, reasonable limitation of working hours and paid annual rest leave.

As for the International Covenant on Economic, Social and Cultural Rights, it is a multilateral international treaty ratified by most UN member states, including Ukraine. This document proclaims and enshrines the human right to work, a fair wage without discrimination, satisfactory living conditions for workers and their families, safe and healthy working conditions, equal opportunities for promotion solely on the basis of labour experience and qualifications level, leisure, participation in the trade union organization and strike.

It is determined that a number of documents for scientific and methodological support of human capital management are approved by heads of organizations, in particular, human capital management policy, corporate code, regulations on corporate roster formation in the organization, regulations on organization of employees' adaptation, recommendations on personnel selection, regulations on personnel incentives, regulations on personnel evaluation, regulations on training and retraining of personnel, instructions on safety rules and regulations on the competition for the title of the best in the profession, but it should be remembered that organizations must comply with the provisions of general, sectoral and regional agreements development of own normative documents concerning the sphere of hunan capital management of the organization.

Regarding the next component of the theoretical and methodological basis of resourcing the human capital management of the organization, which is necessary for proper and effective performance of human capital management functions of HR staff and heads of organizations, the framework of material and technical base of human capital management is a workplace - a spatial area equipped with labour objects in which the work of 
an employee or group of employees is carried out. The organization of the workplace is understood a set of measures for its rational spatial arrangement and equipping with the necessary means and objects of labour.

It is noted that when organizing workplaces one should take into account the requirements of ergonomics, labour protection, production aesthetics, recommendations of physiology, psychology, occupational health. It is very important to provide human capital management with modern technical means. This makes it possible to increase the productivity of managers or employees of the HR staff, speed up the processing of information, improve the quality and efficiency of human capital management decisions, as well as the managerial work culture. According to expert estimates [3], through the use of various facilities, including office equipment, document preparation, copying and reproduction of documents, documents processing, storage, retrieval and transportation of documents, management communications, organizational equipment reduces the complexity of certain types work with documents 3-4 times.

According to V.I. Dovbenko, V.M. Melnyk [4] ta V.A. Savchenko [9], when determining the need for technical means one should take into account the functions and tasks of HR Departmemt, complexity and timing of work, the level of automation of human capital management functions, types of media and volumes of input and output information, information frequency, requirements for processing information, methods and frequency of information transfer, requirements for speed and transmission reliability, remoteness of information sources from the processing centre, terms of information storage, number of its consumers, etc. When choosing equipment one should take into account its purpose, technical characteristics, performance, cost, required area for the location, the requirements for users' professional qualification level and competencies.

Therefore, the use of technical equipment requires the creation of safe conditions for their operation, measures to prevent injuries and occupational diseases. To prevent adverse effects on human health, it is necessary to follow such recommendations as equipping workplaces and arranging them in accordance with ergonomic requirements, use air conditioning or exhaust ventilation systems, set intermittently regulated breaks for rest, etc.

Along with the regulatory and legal, scientific and methodological, logistical support the human capital management requires significant financial resources, which is the last fourth component of the theoretical and methodological basis of resourcing the human capital management of the organization (Fig. 1). In general, human capital management experts [1,7] note that the financing of human capital management entities should include the following costs - the maintenance of human capital management entities (line managers, HR staff) and the performance of human capital management functions of the organization.

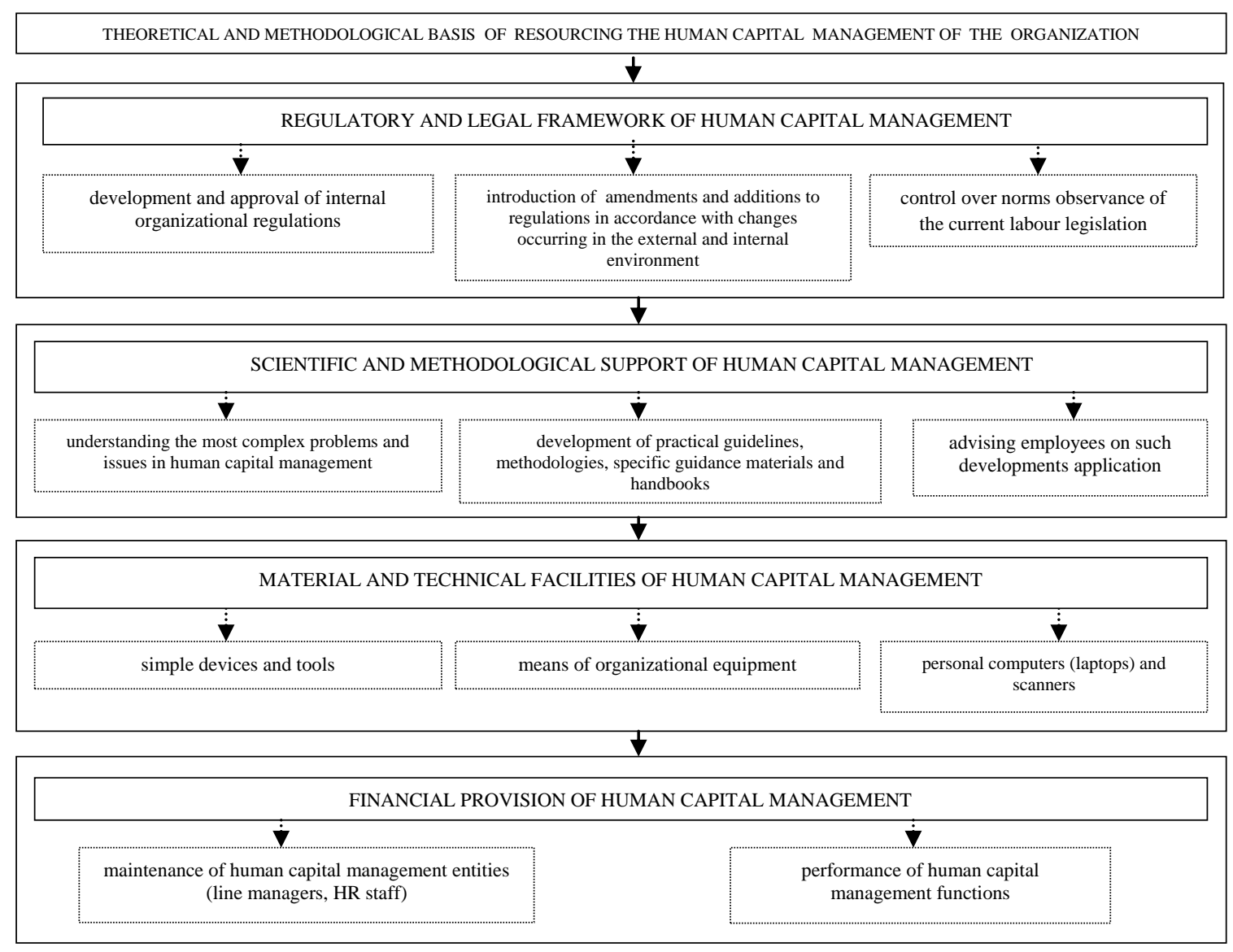

Figure 1. Components of the theoretical and methodological basis of resourcing the human capital management of the organization

Source: authors' own development 
Regarding the costs of maintaining human capital management entities, employers' actual costs for staff, ie the cost of labour, are determined by the following groups: direct payment, overtime pay, bonuses and irregular payments, wages in kind, benefits in kind and cash, the housing costs for employees, the social security costs for employees, the vocational training costs, the maintaining public services costs, taxes related to labour costs.

However, in our opinion, the costs of performing the human capital management functions should include the cost of advertisements in the media, recruitment services, fees for external consultants, the cost of renting premises for interviews and testing, etc. Personnel training costs include tuition fees, lecturers and trainers' salaries who are not in the staff, the cost of renting premises for classes, logistics of corporate training centres etc.

According to O.V. Krushelnytska and D.P. Melnychuk [6],the organization of human resources evaluation may include costs associated with the services payment of external evaluation centeres or the creation of its own centres, the payment of external consultants involved in the evaluation procedure development and its implementation, etc. In addition, the introduction and use of automated information technology of human capital management requires the purchase of computers, basic software, automated staff management system, local area networks installation, training of information technology specialists, line managers, HR staff, technical support, etc.

Thus, it is established that the financing activities in the field of human capital management requires significant costs. The management of many domestic enterprises does not pay due care to the financing activities in the field of human capital management. As a result, during periods of declining business activity, the selection costs, employees' training, the creation of favourable working conditions, renumeration, social security are first and foremost reduced. In the world developed countries the activities in the field of human management are considered as profitable, and personnel costs - as an investment.

In this regard, the paper substantiates and forms the theoretical and methodological basis of resourcing the human capital management of the organization, which consists of the regulatory and legal framework of human capital management, scientific and methodological support of human capital management, material and technical facilities of human capital management and financial support of human capital management, which is necessary for the proper and effective performance of human capital management functions by HR staff and heads of organizations. Since the different vulnerabilities of various companies are explained by distinquishing features in the quality of human capital management and that is why working with people requires a clear regulation of the rights and responsibilities of the parties to social and labour relations and their compliance with established rules, regulations and procedures.

\section{Conclusions}

It is proved that enterprises must comply with the provisions and norms of general, sectoral, regional agreements when developing their own regulations relating to human capital management, as the different vulnerabilities of various companies are explained by distinguishing features in the quality of human capital management. That is why state administration bodies adopt the relevant legislation, because working with people requires clear regulation of the rights and obligations of the parties to social and labour relations and compliance with established rules, norms and procedures.

It is determined that a number of documents for scientific and methodological support of human capital management are approved by heads of organizations, in particular, human capital management policy, corporate code, regulations on personnel reserve formation, regulations on organization of employees' adaptation, recommendations on personnel selection, provisions on personnel incentives, regulations on personnel evaluation, regulations on personnel training and professional improvement, instructions on safety regulations, but it is important to bear in mind that organizations must comply with the provisions and norms of general, sectoral and regional agreements when developing their own regulations in the area of human capital management.

It is noted that when determining the need for technical equipment one should take into account the functions and tasks of HR staff, volume, complexity and timing of work, the automation level of human capital management functions, types of media and volumes of input or output information, frequency of information, requirements for processing information, methods and frequency of information transfer, remoteness of information sources from the processing centre, terms of information storage, number of its consumers, etc. In the process of choosing equipment one should keep in mind its purpose, technical characteristics, performance, cost, requirements for consumers' professional qualification level and competencies.

It is established that the financing activities in the field of human capital management requires significant costs. The management of many domestic enterprises does not pay due diligence to the financing activities in the field of human capital management. As a result, during periods of declining business activity, the selection costs, employees' training, the creation of favourable working conditions, renumeration, social security are primarely reduced. As a result, the paper substantiates and forms the theoretical and methodological basis of resourcing the human capital management of the organization, which consists of the regulatory and legal framework of human capital management, scientific and methodological support of human capital management, material and technical facilities of human capital management and financial support of human capital 
management, which is necessary for the proper and effective performance of human capital management functions by HR staff and heads of organizations.

\begin{abstract}
It is proved that the enterprises have to adhere to the provisions and norms of general, sectoral and regional agreements when developing their own normative documents concerning the sphere of personnel management, as different vulnerability of different companies is explained by differences in the quality of personnel management. It is for this purpose that public authorities approve the relevant legislative acts because dealing with people requires a clear regulation of the rights and obligations of parties to social and labor relations and adherence to the rules, norms and procedures established by them.

It is determined that a number of documents for scientific and methodological support of personnel management are approved by heads of organizations, in particular, personnel management policy, corporate code, provisions on formation of personnel reserve, provisions on organization of adaptation of employees, recruitment guidelines, staff incentive provisions, staff evaluation provisions, staff training and development guidelines, safety instructions, but it must be remembered that organizations must comply with the provisions of the general, sectoral and regional agreements under time to develop your own regulatory documents related to the organization's personnel management sphere.

It is stated that when determining the need for technical means, the functions and tasks of the personnel service, the volumes, complexity and timing of the work, the level of automation of the personnel management functions, types of carriers and the amount of input or output information, frequency should be taken into account receipt of information, requirements for the characteristics of information processing processes, methods and frequency of information transmission, remoteness of sources of information from the processing center, time of storage of information, the number of its consumers etc. When selecting equipment, account should be taken of its purpose, specifications, performance, cost, professional qualification requirements and user competences.

It has been found that the financing of $\mathrm{HR}$ activities requires considerable costs. The management of many domestic companies does not pay adequate attention to the financing of activities in the field of personnel management. In this regard, during periods of downturn, costs of recruitment, training of employees, creation of favorable working conditions, remuneration and social security are reduced in the first place. In this regard, the theoretical and methodological basis of the resource management of the personnel management of the organization is formed in this work, which consists of the normative and legal base of personnel management, scientific and methodological support of personnel management, material and technical base of personnel management and financial support of personnel management, which is necessary for the proper and effective performance of personnel management functions by staff members of staff and heads of organizations.
\end{abstract}

\title{
Список літератури:
}

1. Базалійська Н.П. Світовий досвід управління трудовою діяльністю персоналу в країнах 3 розвиненою ринковою економікою / Н.П. Базалійська // Інноваційна економіка. - 2019. - № 1. C.138-142.

2. Балабанова Л.В. Управління персоналом: [підручник] / Л.В. Балабанова, О.В. Сардак. - К.: Центр учбової літератури, 2014. - 468 с.

3. Делія О. Ефективна комунікація в управлінні персоналом / О. Делія // Соціально-економічні проблеми і держава. - 2018. - Вип. 1 (6). - С. 36-40.

4. Довбенко В.І. Потенціал і розвиток підприємства: [навч. посіб.] / В.І. Довбенко, В.М. Мельник. Львів: Вид-во НУ «Львівська політехніка», 2015. - 232 с.

5. Козак К.Б. Удосконалення роботи служби персоналу на підприємстві / К.Б. Козак, Ю.О. Рубан // Економіка харчової промисловості. - 2018. - № 2. - С. 24-28.

6. Крушельницька О.В. Управління персоналом: [навч. посіб.] / О.В. Крушельницька, Д.П. Мельничук. - К.: Кондор, 2016. - 453 с.

7. Михайлова Л.І. Управління персоналом: [навч. посіб.] / Л.І Михайлова. - К.: «Центр учбової літератури», 2017. - 353 с.

8. Мица В.П. Кадрова політика на підприємстві: проблеми і перспективи / В.П. Мица // Актуальні проблеми економіки. - 2018. - № 6 (84). - С. 165-168.

9. Савченко В.А. Управління розвитком персоналу підприємства: [навч. посіб.] / В.А. Савченко. К.: КНЕУ, 2016. -388 с.

10. Щербак В.Г. Управління персоналом підприємства / В.Г. Щербак. - Харків: Вид-во «ІНЖЕК», 2017. $-482 \mathrm{c}$.

\section{References:}

1. Bazalijska N.P. (2019). World experience of management of labor activity of personnel in the countries with the developed market economy. Innovacijna ekonomika, № 1, 138-142 [in Ukrainian]. 
2. Balabanova, L.V., \& Sardak, O.V. (2014). Personnel management. Kyiv: Centr uchbovoyi literatury [in Ukrainian].

3. Deliya O. (2018). Effective communication in personnel management. Socialno-ekonomichni problemy i derzhava, № 1 (6), 36-40 [in Ukrainian].

4. Dovbenko, V.I., \& Melnyk, V.M. (2015). The potential and development of the enterprise. Lviv: Lvivska politexnika [in Ukrainian].

5. Kozak K.B. (2018). Improvement of the work of the personnel service at the enterprise. Ekonomika xarchovoyi promyslovosti, № 2, 24-28 [in Ukrainian].

6. Krushelnyczka, O.V., \& Melnychuk, D.P. (2016). Personnel management. Kyiv: Kondor [in Ukrainian].

7. Myxajlova, L.I. (2017). Personnel management. Kyiv: Centr uchbovoyi literatury [in Ukrainian].

8. Mycza V.P. (2018). Personnel policy at the enterprise: problems and prospects. Aktualni problemy ekonomiky, № 6 (84), 165-168 [in Ukrainian].

9. Savchenko, V.A. (2016). Enterprise personnel development management. Kyiv: KNEU [in Ukrainian].

10. Shherbak, V.G. (2017). Enterprise personnel management. Kharkiv: Vyd-vo «INZHEK» [in Ukrainian].

\section{Посилання на статтю:}

Kulinska A.V. Theoretical and Methodological Basic of Resourcing the Human Capital Management of an Organization / A. V. Kulinska, D. O. Kostyuk, K. G. Topalova // Економічний журнал Одеського політехнічного університету. - 2020. - № 2 (12). - C.37-44. - Режим доступу до журн.: https://economics.opu.ua/ejopu/2020/No2/37.pdf.

DOI: 10.15276/EJ.02.2020.12. DOI: 10.5281/zenodo.4012476.

\section{Reference a JournalArticle:}

Kulinska A.V. Theoretical and Methodological Basic of Resourcing the Human Capital Management of an Organization / A. V. Kulinska, D. O. Kostyuk, K. G. Topalova // Economic journal Odessa polytechnic university. 2020. - № 2 (12). - C. 37-44. - Retrieved from https://economics.opu.ua/ejopu/2020/No2/37.pdf.

DOI: 10.15276/EJ.02.2020.12. DOI: 10.5281/zenodo.4012476. 